PEDAGOGISK FORSKNING I SVERIGE Vol. 25 No 2-3 (2020) ISSN 1401-6788

\title{
Debatt
}

\section{Dubbel närhet och distans behövs inom praktiknära forskning}

\author{
Anders Persson \\ Professor, Utbildningsvetenskap, Lunds universitet \\ Kontakt: anders.persson@uvet.lu.se
}

I ett slag tycks "alla" ha blivit eniga om att praktiknära forskning är en av lösningarna på lärarprofessionens och lärarutbildningens vetenskapliga svårigheter. Skolforskningsinstitutet (2019) talar till och med om en "överväldigande enighet" och 25 av landets lärosäten som bedriver lärarutbildning har på regeringens uppdrag formerat sig för att, inspirerade av läkarprofessionens $\mathrm{ALF}_{-a v t a 1^{1}}$, skapa ett ULF-avtal ${ }^{2}$. Jag deltar själv i verksamheten nationellt inom den grupp av lärosäten som leds av Uppsala universitet och är ordförande $i$ samordningsgruppen för praktiknära forskning som leder arbetet vid Lunds universitet där också skolhuvudmannen Lunds kommun ingår. ULF-projektets ambitioner att försöka få till stånd mera praktiknära skolforskning, tätare samarbete mellan lärosäten och skolhuvudmän och ge bidrag till lärarutbildningens vetenskapliga grund och yrkesrelevans är behövliga.

Det finns en stor litteratur om förhållandet mellan teoretisk och praktisk kunskap som man bör bekanta sig med i detta sammanhang. Polanyi har exempelvis skrivit tankeväckande om tyst kunskap och konkluderat: "vi kan veta mer än vi kan säga” (2013, s. 27), vilket kan utgöra en beskrivning av det praktiska vetande som exempelvis finns i vissa former av yrkesutövning. Men det hör också till saken, vilket Jarvis (1999) visade redan på 1990-talet, att allt fler yrkesutövare är vad han kallade "practitioner-researchers", yrkesutövare som gör sin egen yrkesrelevanta forskning. Sådana yrkesutövare är det möjligen tänkt att lärare ska bli genom att skolans vetenskapliga grund 
lagstiftats, genom att lärarutbildningen förvetenskapligas alltmer och genom praktiknära skolforskning där lärare som licentiander, doktorander och lektorer och/eller tillsammans med forskare vid universitet och högskolor bedriver forskning om egen och andra lärares skolpraktiker. Under förutsättning att skolhuvudmännen kan hålla kvar de forskande lärarna $\mathrm{i}$ skolan och skapa möjligheter för dem att bedriva praktiknära skolforskning, skapas förutsättningar för ökad kunskap om lärares yrkesutövning. Risken finns emellertid att det inom skolan inte finns tillräckliga resurser för forskning och den praktiknära forskningen riskerar då att förvandlas till mer eller mindre ytligt utvecklingsarbete istället för forskning.

Vad är det som gör det vi kallar forskning för forskning? Det finns en rad svar på den frågan men de flesta betonar att forskning handlar om att systematiskt generera kunskap, att göra detta med hjälp av beprövade vetenskapliga metoder och att öppet redogöra för hur forskningsresultaten genererats. För att kunna göra detta måste forskare på ett eller annat sätt kombinera närhet och distans. I ordet närhet ligger ofta något varmt och tilltalande, även om närhet också kan vara klibbig och snokande, medan distans kan signalera saklighet men också kyla. Varma respektive kalla fakta? I ett annat sammanhang beskrev en kollega och jag forskningsprocesser som nödvändiga pendlingar mellan närhet och distans både vid insamling och $i$ samband med analys av material/data (Andersson \& Persson, 1999). Vi listade bl.a. olika kunskapsdimensioner kopplade till närhet och distans, såsom insider/outsider, delaktighet/icke-delaktighet, affektiv neutralitet/ engagemang, subjekt/objekt samt partikularitet/universalitet. Men dessa uppdelningar gäller förmodligen mest "vanlig" forskning, medan den praktiknära forskningen kräver ett slags dubbel närhet och distans: närhet 1 och 2 respektive distans 1 och 2 . Närbet 1 avser yrkes- eller på annat sätt praktiskt verksammas närhet till yrkesutövningen/verksamheten. Distans 1 avser yrkesutövares distans till sin yrkesutövning, t.ex. genom individuell eller kollektiv metareflektion över yrkesutövningen. Närhet 2 är forskarens närhet till det som studeras (exempelvis lärares yrkesutövning) och som beroende på forskningsfråga kan vara nödvändig för att förstå vad som pågår. Här blir det aktuellt att använda metoder som gör det möjligt att komma nära lärares yrkesutövning: "Så att man är nära individerna när de hanterar det livet gör med dem.", för att uttrycka det med Goffman (1989, s. 125). Distans 2 utgörs av olika former av vetenskaplig distans inom såväl datainsamling, analys av data och rapportering av forskning.

Det finns något oreflekterat $\mathrm{i}$ talet om praktiknära forskning. Det finns därför anledning att undra vilka praktiker som forskningen ska vara nära. Är det några andra praktiker än lärarna? Elever? Föräldrar? Rektorer? Skolhuvudmän? Politiska beslutfattare? Nämnda aktörer är vitala om skolforskaren vill förstå skeenden i skolan och förvisso är närhet då viktig men forskarens distans är lika viktig. Ordet "praktiknära forskning" kan - om 
det beskriver en forskningsprocess - riskera att vingklippa forskningen genom att osynliggöra eller åtminstone underbetona forskningens nöd vändiga distans. Om man vill låta bli att måla fan på väggen, vilket ibland är svårt, kan man istället tänka sig att den närhet som ordet praktiknära beskriver helt enkelt handlar om närhet till skolans yrkesutövare och aktörer. I denna betoning ligger då en implicit kritik mot tidigare forskning som inte varit tillräckligt praktiknära eller inte praktiknära på rätt sätt. Men vem är det som ska bedöma vad som är den korrekta praktiknärheten? Är det politiska beslutsfattare? Skolhuvudmän? Skolans praktiskt verksamma aktörer? Forskare? Forskningsråd?

Det är inte alltid lätt att komma nära det som ska studeras. De aktörer som studeras kan ha intressen av att dölja vitala sakförhållanden genom att styra forskares intryck i riktningar som leder fel. Att bli beforskad kan leda till en show, en uppvisning av exempelvis skolans eller undervisningens goda sidor som samtidigt kan dölja andra sidor. Sådan intrycksstyrning3 är helt naturlig när en individ, grupp eller organisation blir betraktad av en annan aktör, t.ex. en utvärderare, kollega eller forskare. För att komma bakom fasaderna behövs därför både närhet och distanserad analys men inte den traditionella arbetsfördelningen mellan praktiknära yrkesutövare och distanserade forskare. Istället behövs både närhet 1 och 2 och distans 1 och 2 . Inom praktiknära skol- och utbildningsforskning bör inte forskare uteslutande sköta distansen och praktikerna närheten.

\section{NOTER}

1 Avtal mellan staten och sju landsting om läkarutbildning och forskning.

2 Utveckling, Lärande, Forskning - en nationell försöksverksamhet kring praktiknära skolforskning som genomförs på uppdrag av regeringen.

3 Begreppet intrycksstyrning kommer från sociologen Erving Goffman (Goffman, 1959), se också (Persson, 2012, 2018).

\section{REFERENSER}

Andersson, Gunnar \& Persson, Anders (1999). Närhet/distans, forskare/informant, forskning/undervisning: några avslutande reflektioner. I Katarina Sjöberg (Red.), Mer än kalla fakta (s. 193-202). Lund: Studentlitteratur.

Goffman, Erving (1959). The presentation of self in everyday life. New York: Anchor books.

Goffman, Erving (1989). On fieldwork (Transcribed and edited by Lyn H. Lofland.). Journal of Contemporary Ethnography, 18(2), 123-132.

Jarvis, Peter (1999). The practitioner-researcher: developing theory from practice. San Francisco, Calif.: Jossey-Bass. 
Persson, Anders (2012). Ritualisering och särbarbet: ansikte mot ansikte med Goffmans perspektiv på social interaktion. Malmö: Liber.

Persson, Anders (2018). Framing Social Interaction. Continuities and Cracks in Goffman's Frame Analysis. London and New York: Routledge.

Polanyi, Michael (2013). Den tysta dimensionen. Göteborg: Daidalos.

Skolforskningsinstitutet. (2019). Merpraktiknära forskning inom utbildningsvetenskapen - en förutsättning för framgängsrik skolpolitik. Skolforskningsinstitutets inspel till den forskningspolitiska propositionen 2020. (Skolforskningsinstitutet Red.). Stockholm: Skolforskningsinstitutet. 